\title{
Pancreatic Thyrotropin Releasing Hormone and Mechanism of Insulin Secretion
}

\author{
Vladimír Štrbák \\ Institute of Experimental Endocrinology, Biomedical Research Center, Slovak Academy of Sciences, \\ Bratislava, Slovakia
}

\section{Key Words}

Insulin • TRH • Pancreatic islets • Glucose $\cdot$ Constitutive and regulatory secretory pathway

\begin{abstract}
Thyrotropin releasing hormone ( $\mathrm{TRH}$; pGlu-His-ProNH2) is expressed also in pancreatic $\beta$ cells where it is colocalized in secretory granules with insulin. High perinatal changes of the TRH gene expression and TRH concentrations in rat pancreatic islets coincide with the perinatal maturation of the adequate insulin secretory responsiveness to glucose and other nutrient secretagogues. TRH secretion from pancreatic islets is stimulated by glucose and inhibited by insulin. Disruption of the TRH gene in knockout mice results in hyperglycemia accompanied by impaired insulin secretory response to glucose. Progress in understanding TRH - insulin relations may be substantial for improving knowledge of pathophysiological mechanisms included in changes of insulin secretion with possible clinical impact. Block of the last step of biosynthesis of $\alpha$-amidated peptides, including TRH by disulfiram (DS) treatment of adult male rats subcutaneously with $200 \mathrm{mg} / \mathrm{kg}$ for five days in our experiments resulted in barely detectable levels of peptidyl-glycine $\alpha$-amidating monooxygenase (PAM) in their pancreatic islets. TRH in physiological concentration ( $1 \mathrm{nM})$ does not affect basal insulin secretion from intact rat pancreatic islets. In contrast, basal insulin secretion from islets of DS-treated rats is four times higher compared to controls and could not be further stimulated by high-glucose. The addition of $1 \mathrm{nM}$ TRH into medium decreased immediately basal insulin secretion in DS (TRH lacking) islets to control level and normalized also their response to glucose. Interestingly, absence of the secretory response to glucose in islets from TRH depleted rats was connected with their increase of insulin content during stimulation. Glucose stimulation together with 1 $\mathrm{nM}$ TRH normalized also insulin content in DS islets. Apparently, high insulin content in islets from TRH depleted animals is a result of block of regulatory secretion pathway redirected to constitutional secretion which was corrected by the addition of TRH. Type 2 diabetes mellitus is a disease characterized by various range from predominant insulin resistance with relative insulin deficiency to a predominant secretory defect with insulin resistance. These symptoms suggest a possible role of TRH dysregulation. In conclusion, presence of TRH in $\beta$ cells ensures appropriate low basal (constitutive) insulin secretion. Release of TRH induced by glucose and possibly by other secretagogues has autocrine effect resulting in directing insulin secretion
\end{abstract}

\begin{tabular}{ll}
\hline Vladimír Śtrbák & Institute of Experimental Endocrinology, Biomedical Research Center, Slovak Academy of Sciences \\
& Dubravska 9, Bratislava 84505 (Slovakia) \\
& Tel. 421903884840, E-Mail vladimir.strbak@savba.sk
\end{tabular}


to regulatory pathway reacting to stimulation. If some defects of insulin secretion could be treated by TRH, various ways of applications (also oral and nasal) could be utilized. Moreover, positive side effects shown in animal experiments may accompany the treatment: TRH has the potential to prevent apoptosis and promotes insulin-producing cell proliferation and has also aging-reversing properties.

\section{Thyrotropin-Releasing Hormone}

Thyrotropin-releasing hormone (TRH; pGlu-His-ProNH2) was initially isolated as pituitary thyrotropin regulating hypothalamic peptide [1, 2]. Later on TRH was found in various locations [3] within the central nervous system (CNS), prostate, pancreas, thyroid, heart, gastrointestinal tract [4-9] serving various physiological functions.

Pancreatic TRH deserves special attention; its potential functions might be very important. TRH immunoreactivity was reported in rat pancreatic extracts 10 years after discovery of its structure [10]. High proTRH mRNA expression was detected in the insulin expressing and streptozotocin sensitive pancreatic cells in late prenatal and early postnatal period of rat $[5,11]$. Dynamics of pancreatic TRH content correlates with proTRH mRNA expression during ontogenesis [5] with a delay about 3 days; TRH mRNA signal reaches maximum at the day of birth, concentration of TRH at the 3rd postnatal day and both parameters decrease thereafter (Fig. 1). TRH is colocalized with insulin in the secretory granules of rat $\beta$ cells $[12,13]$. TRH was also demonstrated in $\beta$ cells in human fetal pancreas [14] and 1 year old infants [15]. Mulla et al. [16] could show TRH mRNA expression in human fetal and adult pancreata, and TRH receptor mRNA expression in fetal but not in the adult human pancreas [16]. This study was using human islet-derived precursor cells.

\section{TRH And Insulin}

Period of high pancreatic TRH coincides with the perinatal maturation of the adequate insulin secretory responsiveness to glucose and other nutrient secretagogues [17] . Grill et al. showed that the obtunded insulin secretion at birth in the rat may apply to all nutrient secretagogues [17]. The secretory limitation cannot be ascribed to faulty glycolysis but must involve some communally shared, probably early, step in stimulussecretion coupling [17]. Injection of streptozotocin (STZ) to adult rats causes rapid and irreversible destruction of pancreatic $\beta$-cells resulting in a severe insulindependent diabetic syndrome. When administered neonatally, the acute effect of STZ is followed by spontaneous $\beta$-cell regeneration and transient return to normal glucose levels within about 1-2 weeks [1822]. Nevertheless, a disturbance

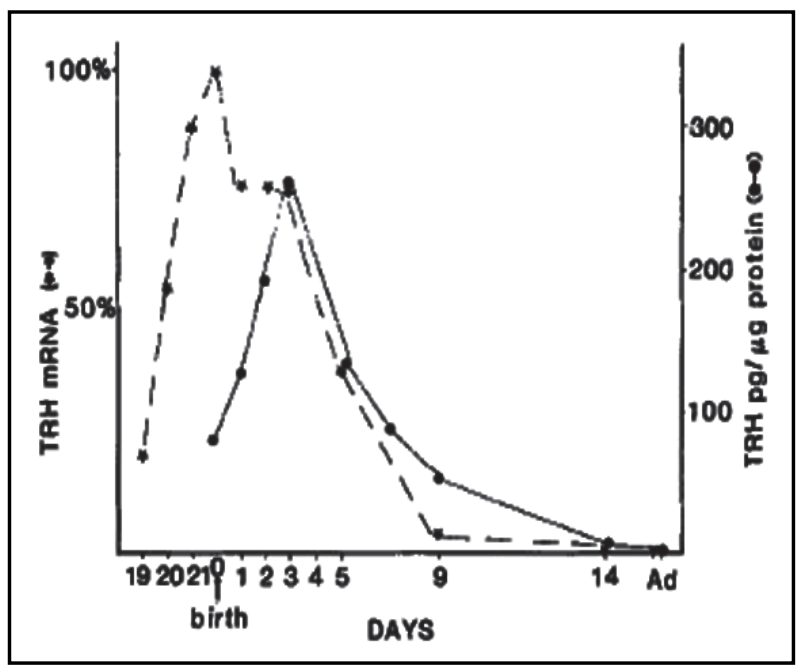

Fig. 1. Ontogenesis of TRH mRNA (expressed as percentage of its level on day 0 ) and TRH pg/ug protein determined by RIA in rat pancreas [5]. $\mathrm{Ad}=$ adult. 
of the insulin response to glucose stimulation persists, thus providing a model for type 2 diabetes mellitus (DM) $[21,23]$. Neonatal STZ (nSTZ) treatment results in parallel depletion of both insulin and TRH in the rat pancreas [19]. Destruction of pancreatic TRH system, in contrast to insulin, is irreversible and does not undergo spontaneous recovery $[12,19]$. Neonatal pancreas contains different types of insulin-containing cells; insulin is colocalized with glucagon in one subpopulation and with TRH in another one [11], which particularly may be irreversibly affected with STZ treatment. Interestingly, when we treated nSTZ rats with TRH during first week of life the insulin response to glucose stimulation

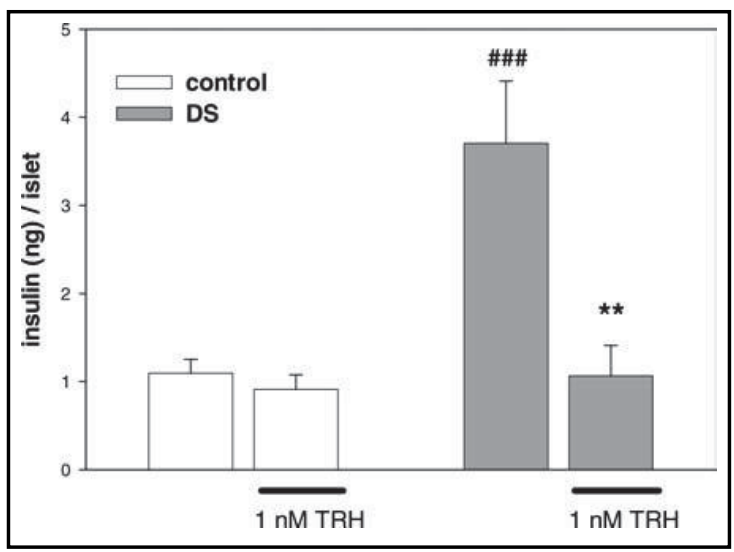

Fig. 2. Effect of thyrotropin-releasing hormone (TRH) on basal insulin secretion from islets from control and disulfiram (DS) treated rats [30]. \#\#\# $\mathrm{P}<0.001$ compared to control group, ${ }^{* *} \mathrm{P}<0.01$ within the DS group. at the age 12-14 weeks was partially restored in females [20]. Hemmings and Spafford [21] also reported lower sensitivity of females to nSTZ. Disruption of the TRH gene in knockout mice results in hyperglycemia accompanied by impaired insulin secretory response to glucose [24].

Secretion of TRH from neonatal rat pancreas is stimulated by glucose [22] and inhibited by somatostatin [22]. Glucose stimulates and insulin inhibits TRH release from isolated adult rat pancreatic islets [25]. All these data indicate specific relation between TRH and glucose-induced insulin secretion. Is it possible that some forms of type 2 diabetes include perturbation of this mechanism? What will happen after inducing acute shortage of TRH in adult animals?

\section{Effect Of TRH Absence And Administration On Insulin Secretion}

Disulfiram (DS) is an effective tool for reducing peptide amidation and decrease of bioactive TRH in vitro and in vivo [26,27]. DS acts as a selective inhibitor of peptidyl-glycine- $\alpha-$ amidating monooxygenase (PAM), the copper-, ascorbate-, and molecular oxygen-dependent enzyme catalyzing the last step of biosynthesis of $\alpha$-amidated peptides, including TRH [28, 29]. Five day pretreatment of adult rats by DS ( $200 \mathrm{mg} / \mathrm{kg}$ body weight subcutaneously daily) in our experiments decreased PAM activity in their pancreatic islets [30] to barely detectable level ( $6 \%$ of those achieved by vehicle treated ones). TRH in physiological concentration (1 $\mathrm{nM}$ ) does not affect basal (Fig. 2) insulin secretion from isolated intact rat pancreatic islets [30]. Basal insulin secretion from islets of DS-treated rats is four times higher compared to controls (Fig. 2) and is decreased to control level after addition of $1 \mathrm{nM}$ TRH into medium [30].

Glucose stimulated (Fig. 3A) insulin secretion from intact rat pancreatic islets is not affected by the presence of $1 \mathrm{nM}$ TRH [30]. The same dose of TRH has very dramatic effect on basal and glucose stimulated insulin release from TRH depleted islets (Fig. 3B) [30]. High release of insulin from DS-treated pancreatic islets under basal (unstimulated) conditions (Fig. 3B) could not be further stimulated by high-glucose (Fig. 3B). Presence of 1nM TRH in the medium during incubation of TRH depleted pancreatic (DS) islets decreased basal insulin secretion to control level (Fig. 3B) and normalized its response to $16.7 \mathrm{mM}$ glucose in islets from DS treated rats (Fig. 3B) [30].

\section{KARGER}


Interestingly, absence of the secretory response to glucose in islets from TRH depleted rats was connected with the high insulin content (Table 1) [30] . Glucose stimulation together with 1nM TRH normalized also insulin content in DS islets (Table 1). Apparently, high insulin content in islets from TRH depleted animals is a result of block of regulatory secretion pathway which was corrected by the addition of TRH [30].

During the granule maturation process, the newly formed mature dense-core insulin granules proceed to the regulatory secretory pathway as releasable granules, whereas soluble luminal proteins lacking signals enter transport intermediates for the constitutive pathway [31,32]. Obviously, islets lacking TRH secrete insulin by constitutive pathway irresponsive to stimulation by glucose (Fig. 4). The addition of TRH redirects insulin from constitutive to regulatory secretory pathway, reflected by decrease of basal secretion and appearance of response to glucose stimulation. Apparently, presence of TRH in $\beta$ cells ensures appropriate low basal (constitutive) insulin secretion and release of TRH induced by glucose [30] and its autocrine and/or paracrine effect(s) is essential signaling step of directing insulin secretion to regulatory pathway. Similar explanation could be used for mice with targeted disruption of thyrotropin

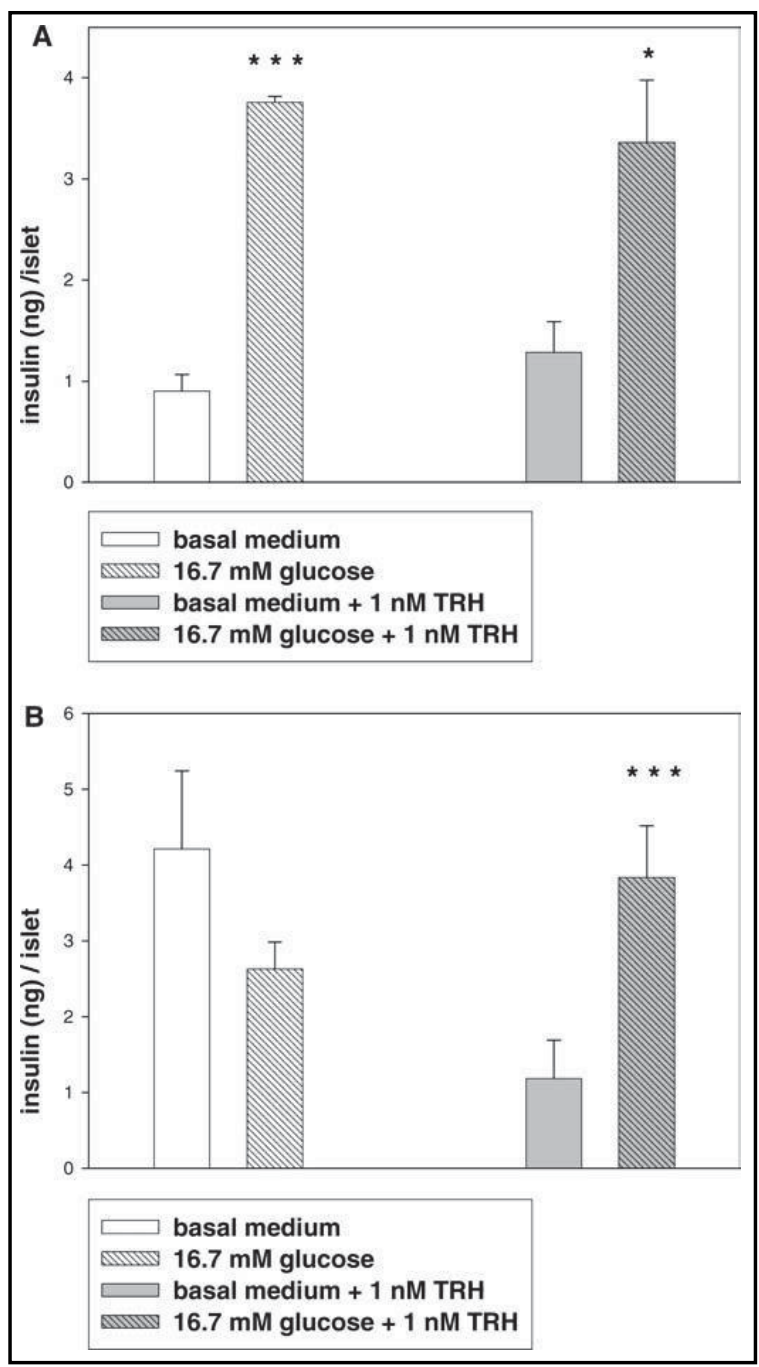

Fig. 3. Effect of TRH on glucose-induced insulin secretion from pancreatic islets isolated from intact (A) and DStreated (B) rats [30]. Islets were incubated for two subsequent $30 \mathrm{~min}$ periods in basal and $16.7 \mathrm{mM}$ glucose media without TRH (left) or with TRH (right). ${ }^{*} \mathrm{P}<0.05$, *** $\mathrm{P}<0.001$ compared with previous incubation. releasing hormone gene; they also exhibit hyperglycemia and impaired insulin secretion in response to glucose [24].

\section{Possible Role Of TRH In Diabetes Mellitus}

Table 1. Insulin content (Means $\pm \mathrm{SE}$ ) (nanograms/islet) in islets from control and DS reated rats after stimulation by $16.7 \mathrm{mM}$ glucose in vitro with or without TRH. NS - not significant. Data from our article [30]

\begin{tabular}{lccccc}
\hline In vitro stimulation: & Glucose & $\mathrm{N}$ & Glucose $+\mathrm{TRH}$ & $\mathrm{n}$ & \\
\hline Control islets & $6.5 \pm 0.5$ & 6 & $8.3 \pm 1.6$ & 7 & $\mathrm{NS}$ \\
DS- islets & $18.2 \pm 2.7$ & 7 & $9.6 \pm 1.2$ & 7 & $\mathrm{P}<0.01$ \\
& $\mathrm{P}<0.001$ & & $\mathrm{NS}$ & & \\
\hline
\end{tabular}

Type 2 diabetes mellitus

(DM) is a disease characterized by various range from predominant insulin resistance with relative insulin deficiency to a predominant secretory defect with insulin resistance. Islets lacking TRH in our experiments [30] release increased amount of insulin at basal conditions without adequate response to glucose stimulation thus making animal model imitating 
Fig. 4. Role of TRH in insulin secretion. Glucose induces TRH secretion from $\beta$ cells and its autocrine and/or paracrine effect(s) is essential signal for directing insulin to regulated secretory pathway with post Golgi insulin granules maturation process. In the absence of stimulation presence of TRH ensures appropriate low basal (constitutive) insulin secretion. In the absence of TRH constitutive secretory pathway without response to stimulation is working: soluble luminal proteins lacking signals enter transport intermediates for the constitutive secretory pathway.

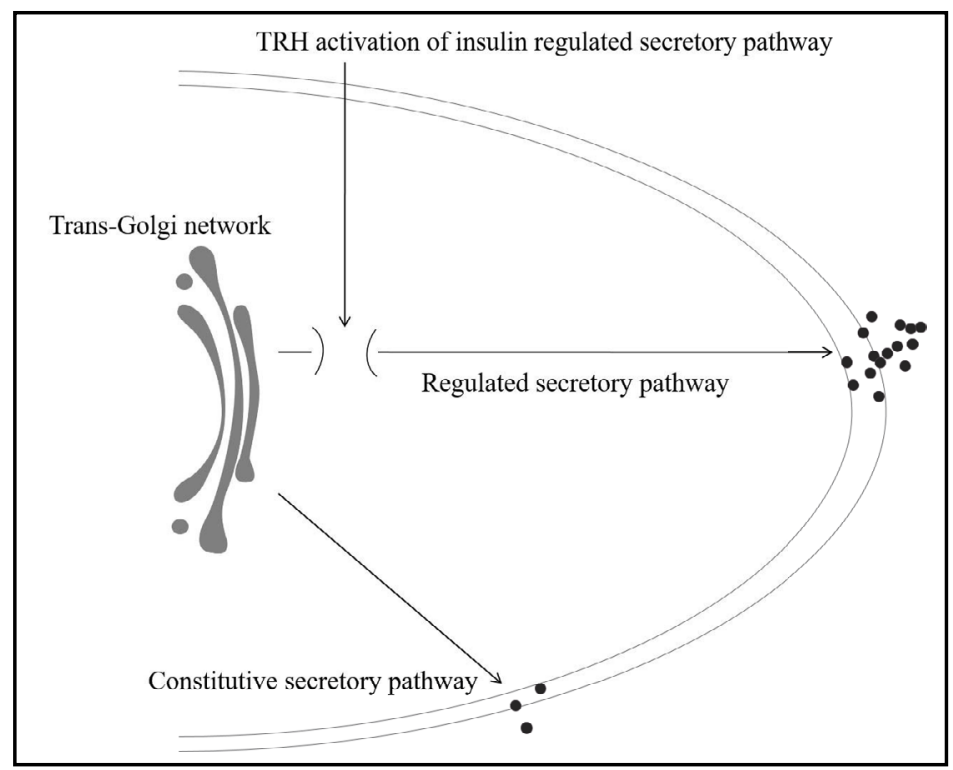

insulin resistance and deficiency as in type 2 DM in patients. Physiological dose of TRH does not affect insulin secretion in intact rat pancreatic islets but has immediate repairing effect on insulin secretion in TRH depleted islets. To our best knowledge no causal effect of pancreatic TRH deficiency on insulin secretion in patients has been reported yet. Nevertheless, it cannot be excluded. Moreover, if some defect in insulin secretion could be treated by TRH, medication could be applied intravenously, orally or nasally. No contraindications were reported for TRH application except for early stages of pregnancy. Side effects may occur after intravenous TRH application. These effects do not last longer than three minutes. They include: feeling of heat, nausea, accelerated heartbeat, dizziness, cerebral pressure, micturition urgency ([33] and Wikipedia) . On the other side it was shown in animal experiments that TRH has the potential to prevent apoptosis and promotes insulinproducing cell proliferation [34] and has also aging-reversing properties [35]. Oral treatment of aging mice by TRH resulted in maintenance and reconstitution of testes structure and function and also protection of kidneys from amyloid and hyaline infiltration [35]. These side effects of TRH therapy could be very positive. On the other hand therapeutic use of TRH may be limited by its rapid blood inactivation and short-term effect in human. TRH analogues have been synhesized and used for various purpose, for instance to increase effect on central nervous system [36, 37]. Development of resistant analogues affecting insulin secretion could be very promissing to prolong duration of the effect and could provide also easier application to patients.

\section{Acknowledgements}

Project was supported by grant VEGA SR 2/0038/18.

\section{Disclosure Statement}

The author declares that there are no conflicts of interest. 


\section{Cellular Physiology Cell Physiol Biochem 2018;50:378-384 \begin{tabular}{l|l} 
and Biochemistry & DOI: 10.1159/000494013 \\
Published online: 4 October 2018 & $\begin{array}{l}\text { (c) } 2018 \text { The Author(s). Published by S. Karger AG, Basel } \\
\text { www.karger.com/cpb }\end{array}$
\end{tabular} \\ Štrbák: Pancreatic Thyrotropin Releasing Hormone and Mechanism of Insulin Secretion}

\section{References}

1 Boler J, Enzmann F, Folkers K, Bowers CY, Schally AV: The identity of chemical and hormonal properties of the thyrotropin-releasing hormone and pyroglutamyl- histidyl-prolineamide. Biochem Biophys Res Commun 1969;37:705-710.

2 Burgus R, Dunn T, Desiderio D, Guillemin R: Structure moléculaire du facteur hypothalamique hypophysiotrope TRF d' origine ovine: mise en évidence par spectrométrie de masse de la séquence PCA His-Pro-NH2. CR Acad Sci (D) (Paris) 1969;269:1870-1873.

3 Lechan RM: Update on Thyrotropin Releasing Hormone. Thyroid Today 1993;16:1-11.

$>4$ Cockle SM, Aitken A, Beg F, Smyth DG: A novel peptide, pyroglutamylglutamylproline amide, in the rabbit prostate complex, structurally related to thyrotropin-releasing hormone. J Biol Chem 1989;264:77887791.

-5 Dutour A, Giraud P, Kowalski C, Ouafik L,H, Salers P, Štrbák V, Oliver C: Ontogenesis of TRH mRNA in the rat pancreas. Biochem Biophys Res Commun 1987;146:354-360.

-6 Carnell NE, Feng P, Kim UJ, Wilber JF: Preprothyrotropin-releasing hormone mRNA and TRH are present in the rat heart. Neuropeptides 1992;22:209-212.

7 Bačová Z, Baqi L, Beňačka O, Payer J, Križanová O, Zeman M, Smreková L, Zorad Š, Štrbák V: Thyrotropinreleasing hormone in rat heart: effect of swelling, angiotensin II and renin gene. Acta Physiol 2006;187:313-319.

$>8$ Iversen E, Weeke J, Laurberg P: TRH immunoreactivity in the thyroid gland. Scand J Clin Lab Invest 1984;44:703-709.

-9 Morley JE, Garvin TJ, Pekary AE, Hershman JM: Thyrotropin-releasing hormone in the gastrointestinal tract. Biochem Biophys Res Commun 1977;79:314-318.

$\rightarrow 10$ Koivusalo F, Leppäluoto J: High TRF immunoreactivity in purified pancreatic extracts of fetal and newborn rats. Life Sci 1979;24:1655-1658.

11 Basmaciogullari CA, Cras-Meneur C, Czernichow P, Scharfmann R: Pancreatic pattern of expression of thyrotropin-releasing hormone during rat embryonic development. J Endocrinol 2000;166:481-488.

12 Leduque P, Aratan-Spire S, Wolf B, Dubois P-M, Czernichow P: Localization of thyrotropin-releasing hormone and insulin-immunoreactivity in the pancreas of neonatal rats after injection of streptozotocin at birth. Cell Tiss Res 1987;248:89-94.

13 Leduque P., Aratan-Spire S, Scharfmann R, Basmaciogullari A, Czernichow P, Dubois PM: Coexistence of thyrotropin-releasing hormone and insulin in cultured fetal rat islets: a light and electron microscopic immunocytochemical study during islet neoformation. Biology of the Cell 1989;66:291-296.

14 Leduque P, Aratan-Spire S, Czernichow P, Dubois PM: Ontogenesis of thyrotropin releasing hormone in the human fetal pancreas. A combined radioimmunological and immunocytochemical study. J Clin Invest 1986;78:1028-1034.

15 Martino E, Grasso S, Bambini G, Pardo G, Vitti P, Aghini-Lombardi F, Pinchera A: Ontogenetic development of pancreatic thyrotropin-releasing hormone in human foetuses and in infants. Acta Endocrinol (Copenh) 1986;112:372-376.

16 Mulla CM, Geras-Raaka E, Raaka BM, Gershengorn MC: High levels of thyrotropin-releasing hormone receptors activate programmed cell death in human pancreatic precursors. Pancreas 2009;38:197-202.

17 Grill V, Lake W, Freinkel N: Generalized diminution in the response to nutrients as insulin-releasing agents during the early neonatal period in the rat. Diabetes 1981;30:56-63.

18 Bonner-Weir S, Trent DF, Zmachinski CJ, Clore ET, Weir GC: Limited $\beta$ cell regeneration in a $\beta$ cell deficient rat model: studies with dexamethasone. Metabolism 1981;30:914-918.

19 Aratan-Spire S, Wolf B, Portha B, Bailbe D, Czernichow P: Streptozotocin treatment at birth induces a parallel depletion of thyrotropin-releasing hormone and insulin in the rat pancreas during development. Endocrinology 1984;114:2369-2373.

-20 Bačová Z, Najvirtová M, Križanová O, Hudecová S, Zórad Š, Štrbák V, Benický J: Effect of neonatal streptozotocin and thyrotropin-releasing hormone treatments on insulin secretion in adult rats. Gen Physiol Biochem 2005;24:181-197.

-21 Hemmings SJ, Spafford D: Neonatal STZ model of type II diabetes mellitus in the Fischer 344 rat: characteristics and assessment of the status of the hepatic adrenergic receptors. Int J Biochem Cell Biol 2000;32:905-919. 


\section{Cellular Physiology Cell Physiol Biochem 2018;50:378-384

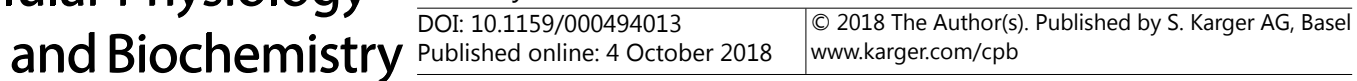 \\ Štrbák: Pancreatic Thyrotropin Releasing Hormone and Mechanism of Insulin Secretion}

22 Dutour A, Giraud P, Maltese JY, Becquet D, Pesce G, Salers P, Ouafik L'H, Renard M, Oliver C: Regulation of TRH release by the cultured neonate rat pancreas. Peptides 1990;11:1081-1085.

-23 Permutt MA, Kakita K, Malinas P, Karl I, Bonner-Weir S, Weir G, Giddings SJ: An in vivo analysis of pancreatic protein and insulin biosynthesis in a rat model for noninsulin-dependent diabetes. J Clin Invest 1984;73:1344-1350.

-24 Yamada M, Saga Y, Shibusawa N, Hirato J, Murakami M, Iwasaki T, Hashimoto K, Satoh T, Wakabayashi K, Taketo MM, Mori M: Tertiary hypothyroidism and hyperglycemia in mice with targeted disruption of the thyrotropin releasing hormone gene. Med Sci 1997;94:10862-10867.

25 Benický J, Štrbák V: Glucose stimulates and insulin inhibits release of pancreatic TRH in vitro. Eur J Endocrinol 2000;142:60-65.

26 Mains RE, Park LP, Eipper BA: Inhibition of peptide amidation by disulfiram and diethyldithiocarbamate. J Biol Chem 1986;261:11938-11941.

27 Rondeel JM, Klootwijk W, Linkels E, van Haasteren GA, de Greef WJ, Visser TJ: Regulation of thyrotropinreleasing hormone in the posterior pituitary. Neuroendocrinology 1995;61:421-429.

-28 Eipper BA, Stoffers DA, Mains RE: The biosynthesis of neuropeptides: peptide $\alpha$-amidation. Annu Rev Neurosci 1992;15:57-85.

29 Mains RE, Dickerson IM, May V, Stoffers DA, Perkins SN, Ouafik L’H, Husten EJ, Eipper BA: Cellular and molecular aspects of peptide hormone biosynthesis, Front Neuroendocrinol 1990;11:52-89.

-30 Najvirtová M, Bačová Z, Matéffyová A, Štrbák V: A role of thyrotropin releasing hormone in insulin secretion by isolated rat pancreatic islets. Pflugers Arch - Eur j Physiol 2005;449:547-552.

31 Hou JC, Min L, Pessin JE: Insulin granule biosynthesis, trafficking and exocytosis. Vitam Horm 2009;80:473506.

-32 Lemus R, Liu M, Turner MD, Scherer P, Stenbeck G, Iyengar P, Arvan P: Lumenal protein sorting to the constitutive secretory pathway of a regulated secretory cell. J Cell Sci 2006;119:1833-1842.

-33 Borowski GD, Garofano CD, Rose LI, Levy RA : Blood pressure response to thyrotropin-releasing hormone in euthyroid subjects. J Clin Endocrinol Metab 1984;58:197-200.

34 Luo L-G, Luo JZQ Jackson I: Tripeptide Amide L-pyroglutamyl-Histidyl-LProlineamide (L-PHP-ThyrotropinReleasing-Hormone, TRH) promotes insulinproducing cell proliferation. Current Aging Science 2013;6:813.

-35 Pierpaoli W: Aging-Reversing Properties of Thyrotropin-Releasing Hormone. Current Aging Science 2013;6:92-98.

-36 Alexandrová M, Strbák V, Kruszynski M, Zboinska J, Kupryszewski G: Two novel thioamide analogues of TRH with selective activity on CNS. Gen Physiol Biophys 1991;10:287-297.

37 Colson AO, Gershengorn MC: Thyrotropin-releasing hormone analogs. Mini Rev Med Chem 2006;6:221226. 